IN F ORMA T I K A

Jurnal Informatika, Manajemen dan Komputer, Vol.11 No.2, Desember 2019

eISSN : 2580-3042

pISSN : 1979-0694

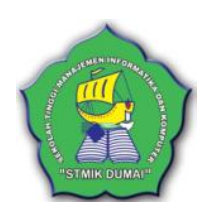

\title{
AIAT PENGIRIS BAWANG OTOMATIS BERBASIS ARDUINO UNO DAN ANDROID
}

\author{
Rizky Nugraha ${ }^{1}$, Haris Tri Saputra ${ }^{2}$, Suwarti $^{3}$ \\ AMIK Tri Dharma Pekanbaru \\ Jl. Jend. Sudirman No. 68 D Pekanbaru \\ Email : rezkinugraha95@ gmail.com ${ }^{1},{\text { haristrisaputra@ } \text { rocketmail.com }^{2}}^{2}$ \\ Suwarty.atd87@ gmail.com ${ }^{3}$
}

\begin{abstract}
ABSTRAK
Pada zaman modern ini alat elektronika sangat dibutuhkan oleh manusia untuk mempermudah pada kegiatan sehari-hari. Alat pengiris bawang berbasis mikrokontroler Arduino Uno dan Android dirancang untuk mempermudah kegiatan pada manusia khususnya kalangan ibu-ibu, sehingga tidak perlu lagi mengiris bawang secara manual sehingga banyak menyebabkan luka dan pedih pada mata pada saat melakukan pengirisan. Penelitian ini menggunakan metode pengumpulan data, analisis, perancangan aplikasi/program, implementasi, dan yang terakhir adalah evaluasi sistem. Maka dari itu dengan adanya alat ini bisa mengurangi kecelakaan pada manusia dan bisa mengiris bawang dengan cepat dan jumlah yang banyak. Dimana alat ini berfungsi untuk meningkatkan proses pemotongan dalam waktu relatif yang singkat sehingga para pengguna tidak merasa rugi pada waktu untuk menyesaikan pekerjaan dapur dan para pengguna bisa mendapatkan hasil yang memuaskan karena bentuk yang pengiris bisa berbentuk sama sesuai dengan yang kita inginkan.
\end{abstract}

Kata Kunci : Pengiris Bawang Otomatis, Arduino Uno, Android

\section{ABSTRACT}

In modern times where electronic devices are needed by humans to facilitate their daily activities. Arduino Uno and Android microcontroller-based onion slicer is designed to facilitate activities in humans that are common among mothers, so there is no need to manually slice onions so that many cause sores and pain in the eye when slicing. Therefore by this tool can reduce accidents in humans and can slice onions quickly and in large quantities. Where this tool serves to improve the cutting process in a relatively short time so that users do not feel the loss in time to finish the kitchen work and the users can get satisfactory results because the shape of the slicer can be the same as they want.

\section{Keywords: Automatic Onion Slicer, Arduino Uno, Android}

\section{PENDAHULUAN}

Pada zaman modern ini di mana alat elektronika sangat dibutuhkan oleh manusia untuk mempermudah pada kegiatan sehari-hari. Seperti contoh alat pengiris bawang otomatis dengan berbasis mikrokontroler Arduino Uno dan Android untuk mempermudah kegiatan pada manusia yang pada umumnya pada kalangan ibuibu, sehingga tidak perlu lagi mengiris bawang secara manual, sehingga banyak menyebabkan luka dan pedih pada mata saat melakukan pengirisan. Maka dari itu dengan adanya alat ini bisa mengurangi kecelakaan pada manusia dan bisa mengiris bawang dengan cepat dan jumlah yang banyak.

Dimana alat ini berfungsi untuk meningkatkan proses pemotongan dalam waktu relatif yang singkat sehingga para pengguna tidak merasa rugi pada waktu untuk menyelesaikan pekerjaan dapur dan para pengguna bisa mendapatkan hasil yang memuaskan karena bentuk yang dihasilkan pengiris bisa berbentuk sama sesuai dengan yang kita inginkan.

Alat pengiris bawang otomatis dengan berbasis mikrokontroler Arduino Uno dan Android ini adalah salah satu alat untuk mendukung hasil peningkatan produksi dalam 
IN F ORMA TIK

Jurnal Informatika, Manajemen dan Komputer, Vol.11 No.2, Desember 2019

eISSN : 2580-3042

pISSN : 1979-0694

pengirisan bawang yang siap digoreng dimana alat ini menggunakan energi listrik yang kecil dan harganya juga relatif murah sehingga bisa digunakan di rumah-rumah untuk pekerjaan di dapur.

Dalam hal ini alat pengiris bawang otomatis berbasis mikrokontroler ini bertujuan untuk memberikan kemudahan pada manusia untuk melakukan pengirisan bawang. Sehingga rangkaian ini sangat berguna bagi manusia untuk mempermudah pada kegiatan sehari-hari apalagi pada era modern saat ini manusia sangat terbantukan oleh rangkaian elektronika yang justru membantu masyarakat dan pada intinya bagi ibu-ibu untuk melakukan pekerjaan dapur.

Alat pengiris bawang otomatis ini menggunakan mikrokontroler modul Arduino UNO sebagai Main Process dan pengolah data, power supply sebagai tenaga listrik pengiris bawang, Motor DC12 Volt sebagai aktuator pengirisan bawang, kemudian bluetooth HC 0.5 sebagai penghubung ke Android.

Pada peneilitian sebelumnya proses pengupasan bawang dalam jumlah banyak yang menggunakan tenaga motor listrik sebagai penggeraknya, Mikrontroler sebagai otak untuk menjalankan proses alat yang dirancang dan sensor berat (Load Cell) untuk menghitung nilai dari kapasitas berat bawang. Kabel ties tersebut berfungsi sebagai pembantu dalam pengupasan bawang dengan cara membenturkanya. Dengan tujuan Menentukan nilai efesiensi ketebalan kulit kupas dan kapasitas berat dari bawang, sehingga variasi yang paling bagus untuk digunakan adalah variasi kombinasi dengan nilai efesiensi sebesar 17\% untuk ketebalan dan 3\% untuk kapasitas berat bawang (Aldian, 2019).

Pembuatan mesin pengiris bawang bertujuan yang hendak dicapai adalah dapat membuat mesin pengiris bawang sehingga dapat menjawab permasalahan jika pengirisan bawang dilakukan dalam kapasitas yang lebih besar. Mesin pengiris bawang ini dibuat untuk mendukung peningkatan hasil produksi irisan bawang merah, yang siap digoreng untuk produksi bawang goreng skala industri rumah tangga (Effendi, 2016).

Mesin pengupas bawang merupakan mesin yang digunakan untuk mengupas bawang, mesin ini bekerja dengan menggunakan gerakan putaran motor yang ditransmisikan oleh pulley dan ditransfer menuju ke poros utama. Agar dapat mengupas bawang mesin ini menggunakan karet-karet pengupas yang dipasang pada dinding tabung dengan bentuk seperti poros, Mesin tersebut menggunakan tenaga penggerak motor listrik sebagai tenaga

utamanya dan mempunyai sistem transmisi tunggal yaitu menggunakan pulley diperantarai vbelt. Meskipun mesin pengupas bawang menggunakan sistem kerjanya sederhana yaitu memanfaatkan gerakan putar untuk mengupas bawang, akan tetapi gerakan putaran pada piringan mesin ini sangat berpengaruh terhadap hasil pengupasan bawang tersebut. Bagian utama dari mesin ini adalah sepasang pulley, karet pengupas, poros, motor listrik dan tabung mesin (Hermawan, 2018).

Rancang bangun alat pengiris bawang merah semi mekanis untuk memudahkan penanganan pasca panen ini bertujuan untuk mengetahui desain alat pengiris bawang untuk memudahkan petani dalam penanganan pascapanen, dan juga dapat berfungsi sebagai alat yang dapat digunakan oleh usaha kecil, terutama bisnis bawang merah goreng (Mursidi, 2015).

Pengaruh variasi diameter Pulley pada mesin perajang bawang merah terhadap kapasitas rajangan ini tentang pengaruh variasi diameter pulley yang digerakkan pada mesin perajang bawang merah terhadap kapasitas hasil rajangan dilatarbelakangi oleh produksi dan konsumsi bawang merah di Indonesia cukup tinggi, sehingga dibutuhkan sebuah mesin perajang bawang merah untuk mempermudah dalam penanganan dan pengolahannya (Syahrun, 2019).

Desain Perajang Serbaguna Dengan Tipe Blade Sliding dan Sistem Transfer Tenaga Semi Mekanis Dan Mekanis adalah salah satu unit operasi pengecilan ukuran untuk penanganan pascapanen komoditi umbi-umbian dan buahbuahan. Pengecilan ukuran berfungsi memperluas permukaan bahan hasil pertanian agar mempermudah proses lanjut diantaranya pendistribusian, tahap pengecilan ukuran lanjutan, pengeringan, penggorengan, mempermudah difusi dan osmosis bahan substitusi larutan. Penelitian bertujuan mendesain dan mengimplementasikan alat perajang serbaguna tipe sliding blade bertenaga semi mekanis dan mekanis dengan memperdalam kajian/analisis teknik yang mencakup kapasitas kerja, efisiensi dan kebutuhan energi (Utomo et al., 2017).

Dalam penelitian rancang bangun alat pengiris serbaguna umbi-umbian dapat disimpulkan bahwa perancangan alat pengiris serbaguna umbi-umbian ini dapat direkomendasikan untuk industri kecil dan juga untuk membantu para petani mengatasi hasil panen yang berlebih supaya tidak merugi dikarenakan umbi-umbian yang terlalu lama disimpan dan menyebabkan umbi-umbian 
I N F O R M A T I K A

Jurnal Informatika, Manajemen dan Komputer, Vol.11 No.2, Desember 2019

eISSN : 2580-3042

pISSN : 1979-0694

membusuk (Putra, Octoricoento, \& Ramza, 2018).

Mesin pengupas kulit bawang Tipe VakumPneumatik (MPB TEP-0315) hasil modifikasi perlu dideskripsikan spesifikasi dan kelayakan ekonominya. Dengan munggunakan metode analisis deskriptif eksplanatori untuk mengamati mengukur, dan menghitung kinerja mesin serta kinerja ekonomi (Wahyu, 2017).

\section{METODOLOGI PENELITIAN}

Penelitian ini dilakukan dan dapat diselesaikan melalui lima tahapan penelitian yaitu (1) pengumpulan data, (2) analisis, (3) perancangan aplikasi/program, (4) implementasi d, dan yang terakhir adalah (5) evaluasi sistem.

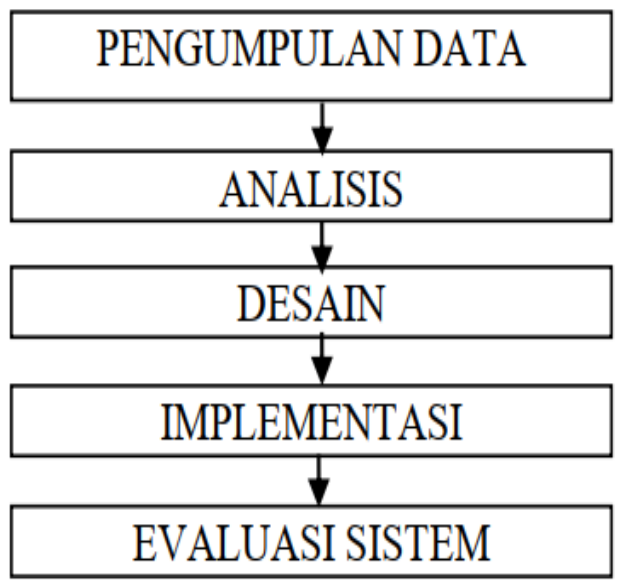

Gambar 1. Tahap Penelitian

Sumber : (Irawati, Sinaga, \& Lubis, 2018)

\section{HASIL DAN PEMBAHASAN}

a. Pengujian Sistem

Pengujian sistem dari Arduino Uno, bluetooth dan Motor DC pada pengiris bawang berbasis android dapat dilakukan dengan langkah-langkah sebagai berikut :

1. Pertama hubungkan listrik stop kontak ke mesin pengiris bawang Prosesnya dapat dilihat pada Gambar 2 dibawah ini :

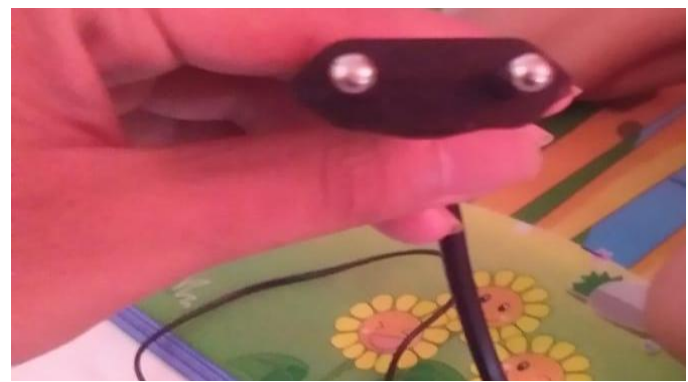

Gambar 2. Menghubungkan Stop Kontak Ke Mesin Pengiris Bawang

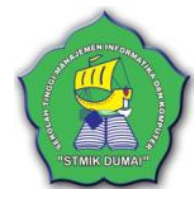

2. Setelah itu mesin pengiris bawang akan menyala. Prosesnya dapat dilihat pada gambar 3 dibawah ini.

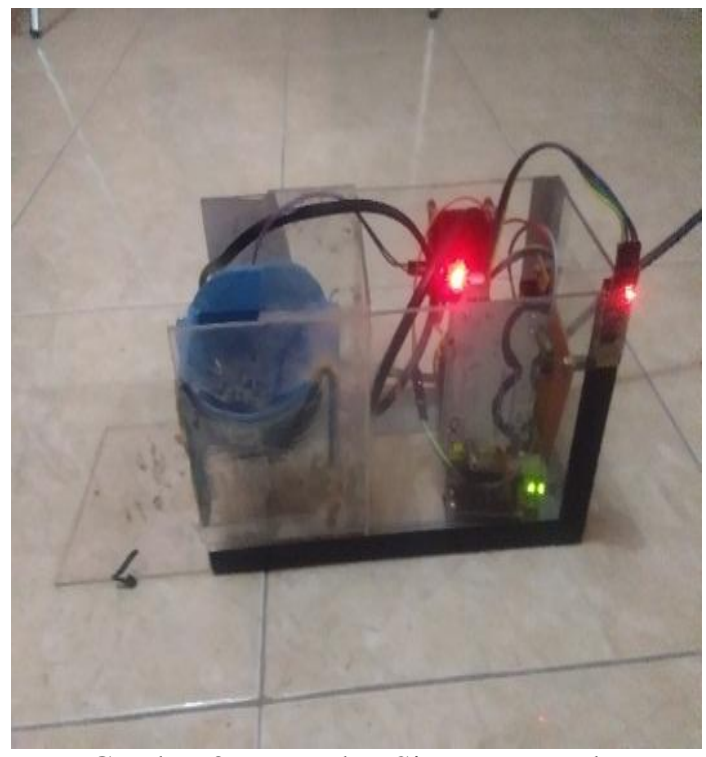

Gambar 3. Perangkat Sistem Menyala

3. Selanjutnya hubungkan android dan mesin pengiris bawang melalui bluetooth

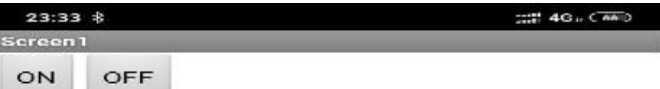

ON OFF

Gambar 4. Proses Menghubungkan Android Ke Mesin Pengiris Bawang Melalui Bluetooth

4. Selanjutnya masukkan bawang di mesin pengiris bawang pada tempat yang sudah disediakan. Prosesnya dapat dilihat pada Gambar 5 dibawah ini. 
IN F ORM T IK A

Jurnal Informatika, Manajemen dan Komputer, Vol.11 No.2, Desember 2019

eISSN : 2580-3042

pISSN : 1979-0694
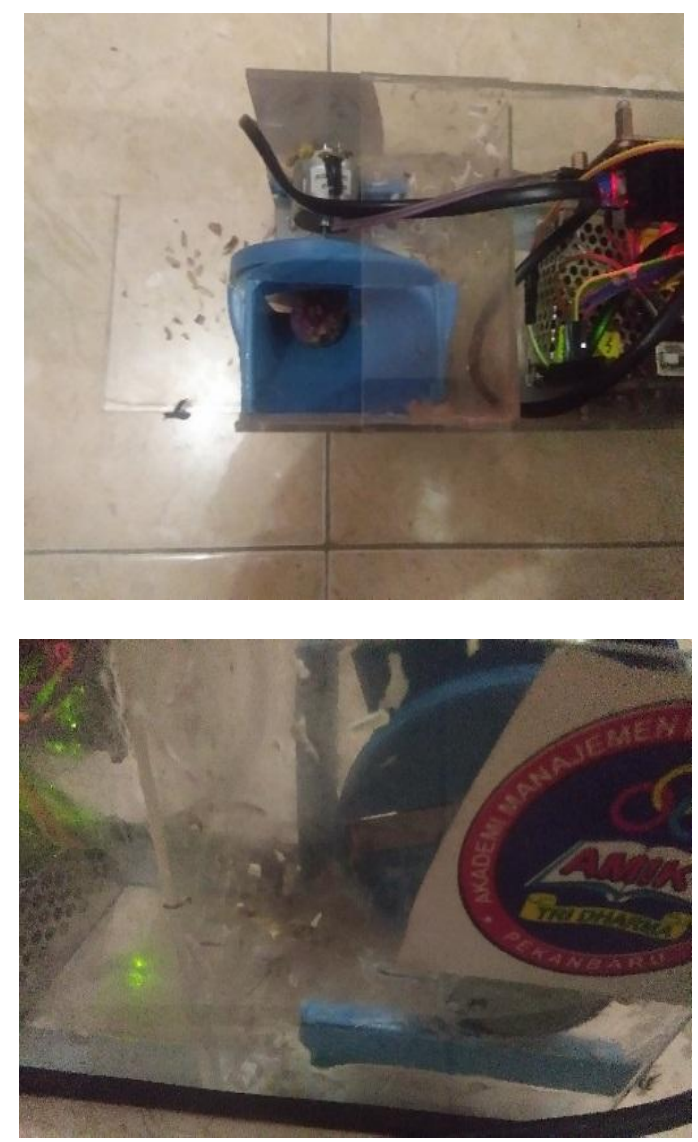

Gambar 5. Hasil potongan bawang

\section{KESIMPULAN}

Berdasarkan hasil penelitian ini maka dapat disimpulkan Alat yang dirancang ini sangat membantu dalam proses pengirisan bawang secara banyak karena memakai sedikit pekerja dan tentunya lebih efisien dalam pengeluaran biaya produksi. Kemudian Komponen yang digunakan antara lain mikrokontroler modul Arduino UNO sebagai Main Process dan pengolah data, power supply sebagai tenaga listrik pengiris bawang, Motor DC12 Volt sebagai aktuator pengirisan bawang, kemudian bluetooth HC 0.5 sebagai penghubung ke Android. Saran untuk pengembang aplikasi ke depan adalah semua komponen yang digunakan dalam pembuatan pengiris bawang berbasis android harus dalam keadaan baik juga berfungsi sebagaimana mestinya dan diharapkan sistem keamanan ini dikombinasikan dengan $R T C$ dan sensor optik.

\section{REFERENSI}

Aldian, R. (2019). Pembuatan Mesin Pengiris Bawang, 12(1), 24-31.

Effendi, Y. (2016). Rancang Bangun Alat Pengiris Serbaguna Umbi-Umbian. 